\title{
TAX CODE OF THE RUSSIAN FEDERATION AS A LEGAL FORM OF ENSURING NATIONAL TAX SECURITY
}

\begin{abstract}
Codified legislative acts (Tax Code of Russian Federation, the Russian Code of Administrative Offences, Criminal Code) play a special role in ensuring tax security among other ordinary laws, because they are designed systematically to organize the groups of public relations developing with the participation of taxpayers and representatives of public authorities. That is exactly why codified acts can most effectively resolve the most complex and serious threats to security in the tax sphere. This article presents solutions for the Russian tax law codification.
\end{abstract}

\section{Key words}

Tax code; national tax security; public governance

\section{Introduction}

National tax security can be described as a situation of the state when the amount of collected taxes corresponds to the number of planned tax revenues taking into account the need for full funding of all functions and tasks of the state and municipalities both in the current period and in the future [Kostukov, Maslov 2015, p. 119].

Such situation could be achieved only by systematic and continuous work of all participants of public relations.

Provision for tax security may be implemented by using a range of methods and various forms.

The theory of legal forms of administrative activities was developed greatly in the science of administrative law and public administration [Atamanchuk 2006; Lunev 1977; Tikhomirov 1987]. Such forms are traditionally divided into legal (the edition of the normative and individual legal acts, the performance of legally significant actions)
[Alekhin, Kozlov 1994, pp. 178-180] and non-legal forms (the implementation of organizational activities and logistical operations) [Starilov 2007, p. 336].

If we consider public governance in a broad sense as a regulating effect of all public authorities in the spheres of public life [Starilov 2002, p. 118], we must recognize that the implementation of such administration in legal forms is a legal provision itself.

Constitutional and ordinary laws (and the Constitution, of course) are the most significant among the legal forms of governance (taken in the broad sense), because rules for social life, which are set in such laws, have supreme legal force.

Codified legislative acts (Tax Code of Russian Federation, the Russian Code of Administrative Offences, Criminal Code) play a special role in ensuring tax security among other ordinary laws, because they are designed systematically to organize the groups of public relations developing with the participation of taxpayers and representatives of public authorities. That is exactly why codified acts can most effectively resolve the most complex and serious threats to the security in the tax sphere.

\section{Main part}

The threat to the security is usually understood as "an event or set of events that directly affect the existence of the subject and are able to entail the termination of this existence or significantly impair it" [Guskov, Reznik 2013, p. 86]. Meanwhile, not only events (facts that do not depend on the will of the people), but also the actions of specific actors can significantly worsen the conditions of tax revenue. 
Threats to tax security can be divided, depending on the participation of certain actors, into:

A) those, which come from taxpayers and other participants of legal relations, not possessing imperious powers;

B) those, which are made by the tax administration and other public authorities;

C) those, which are made by the authorities of foreign states and international organizations.

Threats of the first group include tax evasion in all its forms (starting from the deliberate perpetration of tax crimes to technical errors due to incorrect understanding of the legislative requirements), as well as facilitating evasion or resistance.

Second group of threats may be divided into the threats of legislative and law enforcement nature. Legislative threats are the arbitrary imposition of excessive tax burden and administrative barriers for entrepreneurial activities, a difficult form of presentation of the law-making requirements, omissions and conflicting nature of the law. Law enforcement threats are arbitrary tax administration with the aim of achieving a planned management performance by deliberate disregard of the requirements of the law or the use of defects of its legal technique, the corruption offenses.

Threats of the third group can be divided into the decisions of supranational institutions whose member the State is, the actions and decisions of other states. Tax competition may contribute to the improvement of the tax system of the competing states, but when it is associated with the benefits of an administrative nature (in particular, the concealment of information on the beneficiaries of the business) it poses a serious challenge to the sovereignty and security of other countries.

Focus on the most consistent threats to the national tax security can be traced in the Tax code of the Russian Federation, because this legislative act is aimed at systematical regulation of the relationships arising solely in the field of taxation.

The adoption of the two parts of the Tax code of the Russian Federation in the late 1990s - early 2000-ies cannot be assessed otherwise as a revolution in the regulation of relations arising in the sphere of taxation. This assessment is due to the following characteristics of the Tax code of the Russian Federation:
- it firstly established tax principles, tailored to verified legal positions of the constitutional Court of the Russian Federation and aimed at protecting the rights of taxpayers to use entrepreneurship freely. The principles of interpretation of all unremovable doubts, contradictions and ambiguities of law in favor of the taxpayer ("in dubio pro reo") are particularly important in law enforcement;

- the Code limited subordinate rule-making, rule-making of subjects of Federation and municipal entities in the tax area, which previously led to uncontrolled weighting of the tax burden;

- the Code has streamlined the rights and obligations of taxpayers and tax administration in procedural relations;

- economically reasonable elements of specific taxes were fixed in the Code (for example, proportional tax rate on income tax for individuals; an open list of deductible expenses for tax on profit for organizations).

The tax code continues to respond adequately to emerging challenges in many aspects. So, concise rules of Article 40 (that allowed taxpayers to abolish any tax claim to the prices for formal reasons), were replaced by the specialized section V. 1, consisting of twenty five articles, to minimize the danger of tax evasion through transfer pricing.

The consolidation in 2017 of the rules of collection of insurance fees to state extra-budgetary funds, which are mandatory public law payments, of the Tax code of the Russian Federation should be evaluated positively in the context of increasing the efficiency of the administration. The rules previously established in the Federal Law of 24.07.2009, № 212-FZ for the most part (especially in the procedural part) retold the provisions of the Tax Code of the Russian Federation. However, this retelling contained gaps and contradictions, worsening the rights of taxpayers and promoting tax evasion. For example, the rules of granting the deferment of insurance fee payment was adopted in the Law No. 212-FZ only after five (sic!) years after adoption of this law. We believe that the transfer of similar features for administering the collection of insurance fees and taxes under a unified authority will not only streamline administration, but will make various aspects of performance of the obligation to pay fees more clear and convenient for taxpayers. 
From the point of view of reducing the threat of excessive administrative pressure on taxpayers we should positively evaluate the changes introduced by the federal law of 1.05.2016 in paragraph 2 of the Article 93 of the Russian Tax Code, which allowed to provide scanned copies of documents to tax authorities.

Streamlining the rules of electronic document flow in the Tax Code of the Russian Federation also increases the efficiency of tax authorities to counter the threat of tax evasion by computerized analysis of indicators of taxpayers economic activity and automated detection of tax offences.

However, the Tax Code is not without drawbacks, which discourage effective neutralization of threats to the national tax security.

A number of legal principles of taxation developed in the jurisprudence should be urgently fixed in the Tax Code of the Russian Federation, because it is the most obligatory and stable legal act. It is, first and foremost, actual for the principle of inadmissibility of the abuse of right in tax relations (unjustified tax benefit). This principle is quite elaborated in the judicial practice, but because of variability of the practice it may cause legal uncertainty to taxpayers. For example, even the explanations of the Plenum of the Supreme Court of the Russian Federation change its meaning by interpretation in subsequent decisions of the Court.

Frequent and chaotic changes to the Tax Code of the Russian Federation create unconditional ground for violations (primarily unintentional) of tax rules. Changes in the first part of the Tax Code of the Russian Federation have been made by 103 Federal Laws over 18 years of its existence. If taken into account the duration of the tax period for the main taxes and the rule setting that changes come in force from the beginning of the new tax period, it would be prudent to fix a rule about the inadmissibility of making the text changes by more than one Federal law during a quarter. Such innovation would contribute to the streamlining of the rulemaking, and to facilitating the execution of the changing rules by participants of tax relations.

\section{Conclusion}

The legal nature of responsibility measures stipulated by the Tax Code of the Russian Federation is disputable. We believe that offences described in the Tax Code (according to the elements of their composition and degree of public danger) and punishment (according to degree of severity) do not differ significantly from those embodied in Chapter 15 of the Russian Code of Administrative Offences, and the duplication of norms only complicates their correct application and leads to conflicts. For example, oneyear statute of limitation of administrative responsibility for violation of legislation on taxes and fees, established in the Art 4.5 of the Russian Code of Administrative Offences, does not take into account the three-year period of coverage of a field tax audit. This situation often leads to the impossibility of imposing administrative sanctions on the offenders. Consolidation of rules of all the offences in tax sphere in a separate Chapter of the Russian Code of Administrative Offences would more effectively counteract the threat of tax evasion due to the synergistic effect.

Thus, the Tax Code is the key legal form of ensuring national tax security. However, the provisions of the code require not conceptual, but a tactical improvement in order to counteract emerging threats to national tax security more effectively.

\section{Bibliography}

Alekhin A.P., Kozlov Yu.M. (1994), Administrative law of the Russian Federation. Part 1, M.

Atamanchuk G.V. (2006), Theory of state governance, M.

Guskov Yu., Reznik E. (2013), Security: the problem of understanding the nature, "The Power" No. 11.

Kostukov A.N., Maslov K.V. (2015), Legal aspects of ensuring national tax security, "Bulletin of Omsk University. Law Series" No. 4 (45).

Lunev A.E. (1977) (ed.), Methods and forms of state governance, $\mathrm{M}$.

Starilov Yu.N. (2002), The course of General administrative law. History. Science. Object. Norm. Subjects, M.

Starilov Yu.N. (2007) (ed.), The General administrative law, Voronezh.

Tikhomirov Yu.A. (1987), Legal ensuring of governance, M.

\section{Author biography:}

Alexander Kostiukov - Professor and Doctor in Law, Department of Constitutional and Municipal Law of Omsk F.M. Dostoevsky State University, Russian. 